\title{
疼痛治療における国際卒後臨床コース に出席して
}

本年 9 月22日から 27 日まで、イタリーの Vicenza において第 1 回疼痛治療における国際 卒後臨床コースが開かれ、日本麻醉科学会会 長、佐藤暢教授の推せんのもとに、ハリ治療部 門の講師として出席した。

学会の特徵は、疼痛治療の実地臨床を中心 に、関連領域の各科から講義や討論と実技指導 が行われたととであった。

〔 1]学会の進行は、午前中は講演と質疑応答、 午後は、患者の診断と、その治療方針、そし て実技指導であった。てれらは明日えの臨床 に役立つような方法をとり実践的であった。 我が日本東良導絡学会では、毎月第 3 日曜日 に研究会が行われているが、講演以外にあ実 技指導がありての方法と全く相似していた。 〔2〕本学会の会長は、イタリーのVicenza 市内 の Padova 大学の麻酔科教授 Prof. Rizzi で、 そのために、その郊外に会場が設けられた。 Vicenza は、ミラノより高速にのって約 3 時 間半、ローマより約 6 時間、ベニスより 1 時 間半離れたほんとの田舎である。会場の周囲 はレストランむなければ、お店むない。非常 に交通に不便で、会場とホテルの間も約 10 $\mathrm{km}$ 離れている。講師達は朝夕、会場と木 テル間を送迎バスによって、運行されてい た。

〔3]登録

普通・第 1 回国際シンポジウムなどで新し いテーマで開かれた場合、参加者は 300 人位 である。その上、上記の様な不便な場所にも かかわらず 550 人も参加者があった。登録料 は、日本円に換算して、1人 8 万円位で学生 はその半額位であった。
浦和市小野昌子

〔4〕参加者

大半が若手医師と医学生で、その関係で内 容はテキスト的にアレンジされているのが良 かったと思う。しかし、20～30代の若手医師 がこのように熱心に集っているというとと は、痛みの研究治療の将来の発展が、非常に 期待されるという印象を強く感じた。

\section{〔5〕講師陣}

私は別として、ほとんどの講師は、世界の 各々の分野で、トップクラスの教授が集まっ て講義に当った。

例えば、アメリカの Prof. Bonica オラン ダの Prof. Spierdijk, イタリアの Prof. Moricca, 英国の Swerdlow 等の顔ぶれがみ えた。日本からは、群馬大学麻酔科教授で次 年度の日本麻醉学会々長の藤田教授が参加さ れ、追加発表された。

〔6〕実技指導

これは他の学会にみられないユニークさが あった。例えば、三叉神経痛の外科的療法な ぞ、実際に手術をしているとてろを病院の手 術室（会場から大部離れた所にある）功、 テレビモニターで、ナマ中継して学会場に放 映した。その他、神経ブロックや私の良導 絡、ハリ治療やS S P 療法等、スタジオ入り してテレビモニターで会場に放映された。

\section{〔7〕講演}

会期中のプログラムは、良導絡ジャーナル にすでに記載されている。毎日、大きなテー マが一つありそれに関連した $3 \sim 4$ の演題が ある。スピーチは原則は英語で、20分間、質 疑応答40分間、与えられた。

私の講演は第 3 日目で、この日の大きなテ 
一マは、疼痛治療における代理の（特異的）

テクニックであった。その中には、心理的テ クニック、磁場の効果、電気刺激 (T. N. S ) 療法やハリ治療など、いわゆる特異的治療法 があった。

私の演題は Physiological basis and efficacy of acupuncture for pain therapy. す なわち疼痛治療における、ハリの生理学的基 礎とその効果についてである。

これについては、後日、印刷報告する予定 です。この第 3 日目の竹後は特別に映画のセ クションが設けられた。

(1)ハリ麻酔による禀副悬腔手術（小野）

(2)良導絡ハリ治療（故中谷義雄博士）

以上の二本の映画を上映した。ての良導絡 の映画は午後の実技指導に非常に役立った。 心配していた40分の英語での質問時間も、内 容が非常に基礎的な事で安心した。（例えば モルフィネをハリ治療に併用したら、その効 果はどうなるか、など）。

〔8〕学会最終効果判定日

これもこの学会での特徴の一つである。会 期中のまとめとして、実技指導で治療を受け た患者は再び、スタジオ入りして、主治医の 治療法は的確であったか否か、またその効果 判定をインタビューした。

他の学会にみられないプログラムであっ た。すちろん効果判定の討論は、他の学会で あ沢山あった。しかし、この学会では学生の 臨床講義のように、実際に患者を前にして実 技指導を行った、その効果判定は、その担当 医と患者との間で、やりとりされるのが従来 の方法だが全く別の医師である第三者と患者 との間で、その効果判定をチェックし、それ によって評価するというきびしい方法をとっ ていた。この方法で学んだてとは、良導絡の 効果判定む、良導絡以外の他の学会にどしど し進出して発表し、批判を受け、判定をして あらうことが、今後の良導絡の発展のための 大事なポイントになるのではないかと思っ た。

\section{〔9〕症例報告}

午後の患者の䛦断、治療方針、実技指導に
必要な病歴 (19症例) は前むって、講師達に プリントにして渡された。全症例は異った部 位（異った種類）の痛みの、いわゆる難治症 例であった。毎日、この症例の中から $2 \sim 3$ 症例が選ばれて、その患者はスタジオ入りし て、診断され治療の方法をテレビモニター で、会場に放映された。

今回その中から $3 \sim 4$ 症例を紹介する。

\section{A症例 1}

1）53才男性、前日の午後の診断で dumping 症候群を疑われる患者

2) 主訴：右偏頭痛

3 ) 既往症: 1966年 (14年前) 胃切除（胃潰瑒、 十二指腸潰瘍)

4) 現症: 1975年（5 年前）より頭頂部、右前 頭部、右眼窩辺縁部、右首筋の激痛発 作が、毎日毎食後 1 時間後から約 3 時 間続く。

5 ）治療(1)経口的、非経口的麻醉療法を受けた が無効

(2)神経ブロック（マーカイン、デカド ロン) $\left.\begin{array}{l}\text { 右側頭骨筋内 } 6 \text { 回 } \\ \text { 右星状神経節 } 1 \text { 回 }\end{array}\right\}$ 受けたが無効

(3)ハリ治療を 6〜7回受けたが無効

6）診断の際、これだけの病歴では、大切な点 が欠けている。

先ず 1) にX線写真（頭部・頸部之最近の 胃の写真)

2) 眼底検査（うっ血乳頭の有無）

3) E C G

4) Cs スキャン

5 ）脳血管撮影（造影剂による）

6 ) 神経学的諸検査

等の記載がかった。

かようなととからあ、日本の診断技術は、 如何に世界的トップレベルにあるか、まざま ざ感じた。

しかし、ハリ治療に関しては、この痛みが 悪性腫場からでなければ、診断がはっきりし なくても症状の改善は望めるものである。乙 のようないろいろ治療をしてす無勃例に、八 リ治療をいま一度行うことに決めた。 
との case は、ハリ治療くらいでは効果は ないという意見ああった。との日、司会者で あるインドの prof. Singhはもし、ハリ治療 で効果なく失敗しても、決して、恥かしがら ぬようにと気をつかっていた、「そのあとに 私が神経プロックをして、効かして上げるか ら」と自信たっぷりの様子だった。私は、ま だこのような重症例を治療した経験もないの で全く自信がなかった。しかし、こてでひき さがっては、故中谷先生に申し訳けないと思 って、いろいろ作戦を考えた結果、良導絡治 療の原点にたちかえって、全良導絡調整と局 所の反応良導点に雀啄による電気針治療を試 みた。

良導絡カルテは第 1 日目は大分バランスの バラツキがあった。第 3 日目に、 $\mathrm{H}_{2}$ 興、 $\mathrm{F}_{3}$ 抑、 $F_{5}$ 興、第 4 日目 $F_{3}$ 抑、 $F_{5}$ 抑になった。 しかしての患者の良導絡カルテは最初の日か ら、最後の日までFがHより高かった。この ような場合は経験的にメンタルから症状がき ているということを中谷先生から教えられて いた。そこで、この痛みはメンタルからあ非 常に影響されているすのであろうと考え、 mund therapie あ必要の Case であった。

その他、GEP. point と Neck point を加 えて、EAP を行った。

7 ) 治療結果 :

第 1 日目 少し気持が良い。

第 2 日目 激痛発作は相変らずお起こる。 しかし、少し薬の量を減らしてみ た。発作の時間がほんのすこしだ け、短いような感じがする。

ことで、トフラニールとの併用療法をす すめられた。

この患者はトフラニールは、食べるほど 内服していたが、効果なかった、と言って いた。

第 3 日目

やはり、良導絡治療のみにしぼるとに した。疼痛発作はあった。しかし、楽の量 は、大分減らした、発作時間も短くなっ た。次回は、発作時と治療することに決め た。
第 4 日目

疼痛発作がおこるはずの時間に発作が起 らず、感謝の意を表わしていた。

それ以後、私の滞在中は、再発はなかっ た。最後の日まで、全良導絡調整と反応良 導点の治療を続けた Case だった。

\section{B症例 2}

1）68才女性、10年前加ら、リウマチ性多発性 関節炎の診断をうけ、ステロイド療法治療を うけているが、肘、手、滕、足関節痛之頸部 痛のため悩んでいる Case.

両下肢、関節を中心に腫脹、浮腫、変形、 熱感があり、とくに両下肢は、腫脹のため、 はちきれそうだった。

2）治療 : (1)包帯をはずさせた。

(2) P.H.Eの電気針療法（集毛針で 6 Volt に電圧をさげ、集毛針と 患者との間に第三者を入れて、電 圧をさげて治療する方法）てれ を、関節の疼痛にあて刺激。

(3) S S P 療法: 反応良導点に S S P 電極をつけ、 $3 \mathrm{~Hz}$ と $15 \mathrm{~Hz}$ の $\mathrm{mix}$ 波を 5 分間行った。

(4) S.N. 療法：表皮をすくうよう に針を入れ、それに $6 \mathrm{~V} 、 200 \mu$ $\mathrm{A}$ 通電約11回 $7 \sim 8$ 秒間行。 た。

3) 結果 : ロイマチックの痛みは刺激の弱い方 が効果があるので弱い刺激で行った。この方 法は速効性であるが、持続時間が短い、しか し10年来の痛みも改善した。

\section{C症例 3}

1） 54 才男性、4 5 年前 から腰痛症で 2 回 Laminektomie を受けているが腰痛が治らな W Case.

2) 治療 : (1)先ず S S P 療法 反応良導点、 $3 \mathrm{~Hz} 、 15 \mathrm{~Hz}$ の $\mathrm{mix}$ 波30分間、これで約70\%位の痛み の改善を認む。

(2)前屈させ、痛みが残っているとこ ろに、樑バリを入れ、12V、200 $\mu \mathrm{A}$ の雀啄電気針刺激。

3) 結果、現在までの治療で一番良く効果があ 
ったと患者は言った。前屆できぬほどの腰痛

あ、手が床に 15 20cm 近くまで曲がるよう になった。

\section{D应例 4}

1）31才女性、アレルギー性鼻炎と診断、畕閉 のために睡眠障害がある。

2) 治療：(1)全身測定し、全良罂絡調整

(2)局所療法 : 大後頭結節のななめ外 側の $1.5 \mathrm{~cm}$ 位の下から、ハリを瞳 孔に向けて刺入して雀啄電気針刺 激

(3)印堂、櫕竹、迎香と畕根部から悬 翼に向って皮下に雀哦電気針刺激

3) 結果 :

速効性に鼻閉がとれたが、学会最後の日の 患者であったため持続効果がごのくらい続い たかがわからない。

〔10〕おわりに

以上の症例報告であるが、本学会会長をは じめ、多くの医師達は、ハリの勃果はあまり
信用していなかったようだが、私の実技指導 以来、考え方を変えたようであった。 良導絡治療は、学問的には、まだまだ研究 しなければならない点がありますが治療につ いては、世界的にすばらしい治療法であると 思った。

全良等絡調整之、反応良導点沙雀電気刺 激をやれば、何らかの良い成績が上げられ る。

日頃の基礎的なととを真面目に勉強してい れば、その効果はきっと表われる。

私の症例報告は、日本の良導絡の専門家の 先生方には、とくに目新しいととはなかった と思う。

結論として、私のイタリアの経験から、わ が日本の良導絡治療は、世界に冠たる治療で あると思う。ますます先生方の御研さんと御 研究を期待して、今後の本学会の発展を望み ます。 